\title{
Abordagem Temática Freireana no Ensino de Ciências e Biologia: Reflexões a partir da Práxis Autêntica
}

Freirean Thematic Approach in Science and Biology Teaching: Reflections from Authentic Praxis

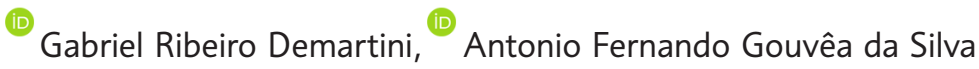

Palavras-chave Resumo O presente trabalho investigou em que medida a educação Abordagem libertadora pode fundamentar práticas curriculares transformadoras

Temática; da realidade sociocultural injusta no contexto de uma escola Tema Gerador; estadual de ensino médio de São Francisco do Brejão (MA). O Paulo Freire; objetivo foi compreender a realidade escolar em seus múltiplos Ensino de Ciências. condicionantes e propor uma práxis curricular crítica. Para tanto, ancorados numa investigação de natureza qualitativa do tipo pesquisa-ação, desenvolveu-se o processo de construção curricular no ensino de Ciências e Biologia mediante a abordagem temática freireana. Observações de campo, análises documentais e relatos permitiram uma caracterização do contexto local juntamente com falas significativas repletas de contradições socioculturais. A partir da análise relacional e distanciada, uma programação curricular foi elaborada de modo a atender as especificidades do contexto. Além disso, com base na problematização, uma mobilização de educandos resultou na construção de uma quadra de vôlei comunitária no Município. Em síntese a educação libertadora apresentou-se como possibilidade ética, política e epistemológica de subsidiar práticas curriculares emancipatórias e dialógicas no contexto do ensino de Ciências e Biologia. Buscando o esclarecimento acerca da dinâmica da investigação temática (Freire, 1987), a presente pesquisa vai ao encontro de outros trabalhos da área que buscam elucidar os processos de representação e análise envolvidos na redução temática. Neste sentido, aponta a vinculação indissociável entre temas dobradiças e temas geradores. 
Keywords Abstract The present work investigated to the extent liberating Thematic Approach; education can support curricular practices that transform the unfair Generator Theme; socio-cultural reality in the context of a state high school in São Paulo Freire; Francisco do Brejão (MA), Brazil. Central objective was to understand Science Teaching. the school reality in its multiple conditions, so as to propose transformative curricular practices to consolidate a humanizing education. As a qualitative action-research, we developed a curriculum plan in Science and Biology using the Freirean thematic approach. Field observations, reports and documentary analysis enabled a characterization of the local context, as well as utterances full of sociocultural contradictions. From the relational and distant analysis, a curricular program was elaborated in order to meet the specificities of the context. In addition, from the problematization, a mobilization of students resulted in the construction of a community volleyball court in the city. In summary, liberating education presented itself as an ethical, political and epistemological possibility of subsidizing emancipatory and dialogic curricular practices in the context of science and biology teaching. Seeking clarification on the dynamics of thematic investigation (Freire, 1987), this research is in line with others in the field that seek to elucidate the processes of representation and analysis involved in thematic reduction. In this sense, it points out the inseparable link between hinged and generative themes.

\section{Introdução}

As questões curriculares assumem centralidade na discussão educacional e tornam-se objeto de intensas disputas por envolverem assuntos de poder, pois valores e conhecimentos são selecionados e direcionados ao processo formativo educacional de milhares de pessoas. Neste sentido, o currículo manifesta interesses políticos, econômicos e culturais de uma sociedade que, ideologicamente, utiliza da esfera educacional para estruturar a produção e reprodução do seu modo de vida hierarquizado com a distribuição relativa da miséria.

Historicamente, em momentos de crise econômica e política a resposta encontrada é a transferência dos problemas para as escolas. É assim que as reformulações educacionais no campo curricular ganham corpo e atuam ideologicamente atendendo às novas demandas da classe dominante (Apple, 2006).

A tese era a de que, se os professores e os currículos fossem controlados mais de perto, estando mais intimamente relacionados às necessidades do mundo empresarial e industrial, mais tecnicamente orientados, com mais ênfase aos valores tradicionais e às normas e disposições do mercado de trabalho, então os problemas de alcance de resultados, de desemprego, de competitividade 
econômica internacional, de desintegração das áreas centrais das grandes cidades, etc., desapareceriam em grande parte [...] (p. 21).

Neste sentido, o cenário político-pedagógico do campo curricular está estruturado para atender aos interesses da classe dominante. Servindo a esta demanda, a pedagogia teve que se consolidar como método de reprodução da passividade, do conformismo, do não desenvolvimento de criticidade, de modo a não confrontar as estruturas de distribuição do poder econômico e político vigentes na sociedade burguesa.

É com uma crítica radical a esta perspectiva, denominada por Freire (1987) de "Educação Bancária", que a pedagogia libertadora apresenta-se como alternativa, um novo projeto educacional que se organiza pela busca da humanização sistematicamente negada para a maioria da sociedade. Para tanto, o conteúdo do diálogo educacional é investigado e não imposto, sendo construído a partir da realidade concreta, num exercício de práxis autêntica (Freire, 1987).

A relevância educacional deste tipo de trabalho consiste em resgatar a autonomia docente no exercício da práxis curricular; em posicionar-se como sujeito da prática que encontra os educandos, com seu mundo e suas expressões, para, juntos, interpretar e transformar a realidade e é aqui que a sua relevância social se faz evidente. Quando sujeitos negados e coisificados se reencontram com sua capacidade criadora e transformadora, a historicidade das formações socioculturais é percebida e não mais temida como insuperável e imutável.

A presente pesquisa foi desenvolvida no C. E. M. Tobias Barreto, única escola de ensino médio de São Francisco do Brejão. Situada no extremo oeste maranhense, marcada pela riqueza natural de seu bioma amazônico, pela ostensiva desigualdade social e por políticas públicas inócuas que limitam grande parte da população a condições indignas de "produção, reprodução e desenvolvimento da vida humana" (Dussel, 2000). Os jovens, em sua maioria, são desassistidos de seus direitos fundamentais, por vezes propagando a aceitação passiva e a naturalização de injustiças sociais.

Neste sentido, o problema de pesquisa que orienta este trabalho se expressa na seguinte questão: em que medida a educação libertadora pode fundamentar práticas curriculares transformadoras da realidade sociocultural injusta no contexto de uma escola estadual de ensino médio de São Francisco do Brejão (MA)? O objetivo é compreender a realidade escolar em seus múltiplos condicionantes e propor práticas curriculares transformadoras que busquem a consolidação de uma educação humanizadora. Para tanto será elaborado um currículo contextualizado por meio do processo de "investigação temática" para a obtenção de um "tema gerador" que possibilite a organização da programação curricular a partir das contradições socioculturais locais (Freire, 1987).

Trata-se de uma pesquisa de natureza qualitativa com abordagem do tipo pesquisa-ação (Franco, 2005; Thiollent, 1986) que buscou partir das contradições socioculturais expressas pela comunidade escolar e articulou a construção de um currículo que ultrapassou os limites da instituição e ganhou concretude no bojo social local. Por fim, relatamos o movimento de organização da comunidade escolar para a 
construção de uma quadra de vôlei de areia num terreno do Município como parte da busca por posicionar-se como sujeito da sua história.

No sentido de contribuir para o ensino de ciências e pesquisas voltadas para a área que adotam a pedagogia freireana como referencial teórico-metodológico, procurouse explicitar a dimensão epistemológica do diálogo articulando com a perspectiva dos valores ético-críticos (Dussel, 2000). Assim, evidenciamos complementaridades e aproximações na busca por desenvolver um projeto humanizador que vivencie a práxis autêntica no processo de investigação temática. Tal processo fundamenta-se em Freire (1987), e busca uma organização coletiva de propostas e programações curriculares que partam da realidade concreta dos alunos. Um dos parâmetros explicitados por Freire para essa dinâmica de construção pedagógica é o tema dobradiça, que muitas vezes foi compreendido como uma temática complementar não associada ao tema gerador e selecionada apenas pela perspectiva dos educadores. Trabalhos como os de Coelho (2010) e Oliveira (2016) abordam a relevância do tema dobradiça para o desenvolvimento do processo de investigação temática no ensino de ciências. O presente artigo promove uma reflexão sobre as articulações dos temas dobradiças com os temas geradores para fundamentar um currículo balizado na práxis autêntica freireana.

\section{Freire e o diálogo na Pedagogia Libertadora}

A pedagogia libertadora não é somente outra teoria pedagógica construída no universo educacional e divorciada da sociedade. Ela precisa ser posicionada em seu contexto de origem para que sua radicalidade seja compreendida. Nesse sentido que percebemos a contribuição da pedagogia do oprimido (Freire, 1987) na construção curricular.

Sua gênese se dá no nordeste brasileiro da década de 1960, submetido à pobreza, à miséria, ao analfabetismo e àquilo que ficou conhecido como "cultura do silêncio". Tal cultura é a imobilidade introjetada no inconsciente coletivo, é a consciência servil, submissa, oprimida, incapaz de transformar a realidade. Essas são características de uma sociedade que nega a comunicação, o diálogo como expressão do mundo. $\mathrm{O}$ analfabetismo, que não se reduz ao não domínio de um código formal de linguagem, atinge também a não leitura do mundo. Por isso, a alfabetização assume na pedagogia libertadora um papel de protagonismo em que é preciso compreender e transformar o mundo em que vivemos, num movimento que exige a libertação dos oprimidos, ou seja, a educação como um ato político emancipador (Freire, 1983).

O diálogo apresenta-se como possibilidade de garantir àqueles que são sistematicamente negados o direito de dizer a palavra, de expor a sua visão de mundo, para, juntos, e partindo dela, educadores e educandos, problematizarem as dimensões ingênuas, fatalistas e limitantes, em um processo praxiológico que busca a construção de uma consciência crítica. Pelo diálogo, que não é qualquer conversa e muito menos 
um devaneio, as contradições socioculturais da realidade são objetos de análise, num desvelamento ideológico que impulsiona para a ação transformadora da situação concreta que desumaniza (Freire, 1987).

O que se está dizendo é que pelo diálogo se inicia a busca do conteúdo inerente ao processo educativo. Este não éimposto ao educando, mas construído com ele, mediatizado pelas condições concretas da existência onde se encontram as visões encharcadas de incompreensões, limites explicativos que implicam em temas significativos para o processo educativo (Freire, 1987).

É mediante o processo problematizador e dialógico que o conhecimento novo será construído, não rejeitando o conhecimento anterior de forma absoluta, mas buscando manter o que for positivo e desvelando suas contradições que levam à desumanização, isto é, à limitação da vida humana. O novo conhecimento ressignificado, amplo e relacional, busca uma compreensão em "totalidade" acerca dos condicionantes da realidade concreta. A negatividade ${ }^{1}$ é o ponto de partida do conteúdo e o diálogo é a expressão ética e estética, o fundamento político-epistemológico da educação como prática de liberdade.

A educação libertadora - que não impõe sobre a realidade um conteúdo educacional, pelo contrário, procura nesta os elementos para a sua organização curricular - constitui pela dialogicidade o ataque mais radical à perversidade epistemológica construída pela “educação bancária”. Isso porque essa perspectiva ideológica denunciada por Freire (1987) compreende o processo epistemológico como um acúmulo de informações transmitidas pelo educador - o sujeito do processo - ao educando sujeito coisificado. Daí que o conhecimento, num movimento mecânico de transmissão, seja comparado aos "depósitos bancários". O conhecimento prévio do educando não é considerado, a relação estabelece uma verticalidade em que o educando nada tem a oferecer.

O equívoco epistemológico está em compreender o ato educativo como uma extensão mecânica de informações - transferência —, tornando estático o conhecimento e dicotomizando verticalmente a relação educador-educando. Para a educação libertadora, o ato educativo é compreendido como um ato de comunicação em que educador e educando encontram-se mediatizados pelo mundo, curiosos e solidários, ambos aprendendo e ensinando e compreendendo a historicidade do conhecimento (Freire, 1983).

\footnotetext{
1 A negatividade pode ser compreendida no campo da ação e do pensamento humano em pelo menos dois planos, o epistemológico e o ontológico. Numa dimensão epistemológica do materialismo histórico dialético, toda antítese é uma negatividade à tese, e toda tese está "grávida", isto é, traz em si a sua negação. Ex: Tese — Realidade velada e alienada, contendo suas contradições. Antítese - denúncia dessa realidade na fala da comunidade, ou seja, são as contradições como problema, são as negatividades. Neste plano que se encontra também o contratema - visão do professor. Síntese - é a negação da negação. É o esforço praxiológico de transformação da situação injusta. É o anúncio. No plano ontológico da negatividade, há a ideia de que o ser humano não pode realizar-se como humano, e isso implica em uma exigência ética, a superação (Silva, 2004).
} 
A base é a condição concreta que oprime, marginaliza e desumaniza, e, ao partir das negatividades para se pensar a organização programática, a pedagogia libertadora demonstra uma racionalidade "ético-crítica" (Dussel, 2000; Silva, 2004). Como diz Freire (2011), “O meu ponto de vista é o dos 'condenados da Terra', o dos excluídos” (p. 16). Neste sentido, é inegável a articulação entre a proposta freireana e a Ética da Libertação dusseliana $^{2}$. Isso porque esta se fundamenta na exterioridade, a partir da negação da vida concreta do excluído, das vítimas do sistema socioeconômico - eurocêntrico. A alteridade é elemento central desta ética, que compreende a negatividade na totalidade das determinações socioculturais e se compromete solidariamente com a afirmação da vida do Outro. Não basta apenas negar a opressão como algo injusto, é necessário afirmar a exterioridade negada (Dussel, 2000).

A posição de neutralidade diante da vítima, do excluído, é impossível ao sujeito ético-crítico, à epistemologia humanizadora. Faz-se necessário assumir uma posição ética universal - mas uma ética histórica, não idealista. Segundo Dussel (2000), a pedagogia libertadora atinge esta posição, pois expressa a impossibilidade da educação crítica do oprimido sem que este se descubra como sujeito no processo de sua libertação; expressa, ao partir das "situações-limites" para a construção programática, a materialidade negativa da educação que se constrói na realidade concreta do educando; expressa que a tomada de consciência da situação que desumaniza deve-se organizar-se em práxis autêntica, por isso, transformadora.

A 'práxis da libertação', para Freire, não é um ato final, mas o ato constante que relaciona os sujeitos entre si em comunidade transformadora da realidade que produz os oprimidos. É a água em que nada o peixe da pedagogia crítica. $\mathrm{O}$ ato pedagógico só se dá dentro do processo da práxis de libertação, que não é só um ato revolucionário, mas todo ato transformativo humanizante em prol dos oprimidos e para que deixem de ser oprimidos (Dussel, 2000, p. 443).

A exterioridade negada, a negatividade da vítima, o excluído, exigem uma racionalidade ético-crítica nas relações pedagógicas e curriculares, por isso a Ética da Libertação e a Pedagogia Libertadora colocam-se como fundamentos para práticas pedagógicas humanizadoras (Furlan, 2015; Santos, 2020; Silva, 2004). Dialogicidade, negatividade e alteridade são componentes axiológicos e epistemológicos fundamentais para processos educativos em geral, embora aqui direcionados para a perspectiva curricular crítica no ensino de Ciências e Biologia.

2 Enrique Dussel é um filósofo argentino, exilado no México, que constrói uma ética da libertação como afirmação não só da América Latina, mas também da Ásia e, África, que são negados pela racionalidade e pelo sistemamundo eurocêntrico - modernidade - a partir da negatividade e alteridade, em favor da vida humana. É uma ética da vida (Dussel, 2000). 


\section{Abordagem Temática Freireana no Ensino de Ciências}

A perspectiva de estruturação curricular via abordagem temática freireana busca selecionar dialogicamente o conteúdo programático do processo educativo a partir da definição de um tema, envolvendo de forma interdisciplinar as diferentes áreas do conhecimento para a compreensão de um fenômeno (Delizoicov et al., 2011). Portanto, apresenta-se como uma alternativa aos tradicionais "pacotes curriculares" produzidos por secretarias de educação e aplicados pelos professores, que sequer foram consultados no planejamento destes e que tratam a realidade concreta de forma marginal.

É na obra Pedagogia do Oprimido de Paulo Freire (1987), precisamente no capítulo três quando se trata do processo de organização programática denominado "investigação temática", que encontramos a fundamentação teórica para a abordagem temática freireana. Diferentemente de outras perspectivas, ela apresenta critérios dialógicos e dialéticos para a definição do tema.

Contudo, por seu desenvolvimento ter ocorrido em experiências educacionais com jovens e adultos em espaços não escolares, a sua utilização em sistemas escolares exigiu reorganizações que, segundo Delizoicov (2008) são alguns dos pontos menos explorados da obra freireana. No sentido de enfrentar e superar as dificuldades oriundas desta readequação, equipes de pesquisadores do ensino de ciências - vinculados à Universidade de São Paulo (USP), à Universidade Federal de Santa Catarina (UFSC), e à Universidade Federal do Rio Grande do Norte (UFRN) - desenvolveram importantes investigações.

Mediante o processo de investigação temática, as "situações-limites" são obtidas. Expressas como visões de mundo fatalistas, repletas de contradições socioculturais que dificultam a compreensão ampla e relacional da realidade concreta, acabam por estabelecer o vínculo entre a práxis curricular autêntica e a existência dos educandos. O Tema Gerador, eixo organizador da programação curricular, é identificado como uma "situação-limite" mais ampla que envolve e é envolvida por todas as outras (Freire, 1987). Em síntese, o tema gerador é aquela temática pulsante na realidade concreta e expressa pelos sujeitos, repleta de negatividades, contradições socioculturais, anseios, dúvidas, angústias, e que lhes aparece de forma cifrada, dificultando a compreensão em totalidade (Silva, 1987).

Além do tema gerador, Freire (1987) também aponta o "tema dobradiça" como importante parte do processo de tomada de consciência da realidade local e estruturação da programação curricular. Respeitando a dialeticidade do processo, são temas não sugeridos que são inseridos pelos docentes como importantes para a compreensão global do tema gerador e do contexto sociocultural.

Neste esforço de 'redução' da temática significativa, a equipe reconhecerá a necessidade de colocar alguns temas fundamentais que, não obstante, não foram sugeridos pelo povo, quando da investigação. A introdução destes temas, de necessidade comprovada, corresponde, inclusive, à dialogicidade da educação, 
de que tanto temos falado. Se a programação educativa é dialógica, isto significa o direito que também têm os educadores-educandos de participar dela, incluindo temas não sugeridos. A estes, por sua função, chamamos 'temas dobradiça'. Como tais, ora facilitam a compreensão entre dois temas no conjunto da unidade programática, preenchendo um possível vazio entre ambos, ora contêm, em si, as relações a serem percebidas entre o conteúdo geral da programação e a visão do mundo que esteja tendo o povo. Daí que um destes temas possa encontrar-se no 'rosto' de unidades temáticas (Freire, 1987, p. 66).

Diversos autores elaboram sistematizações a partir do processo de investigação temática proposto por Freire (1987). Por exemplo, Novais et al. (2017), no contexto de uma escola municipal em Iguaí (BA), tratam do processo de Redução Temática articulado à formação de professores. Neste mesmo sentido, Silva e Gehlen (2016) apresentam contribuições à formação de professores de ciências em Pau Brasil (BA) a partir da aproximação entre Abordagem Temática Freireana e a Práxis Curricular via Tema Gerador. No campo da formação de professores, especificamente em química, Lambach (2013) discute fundamentos da educação freireana dialógica. Silva et al. (2016) também organiza dinâmicas de formação docente a partir de adaptações do processo de investigação temática. Sousa et al. (2014) orientam a construção de atividades didáticopedagógicas a partir da identificação de um tema gerador com professores de ciências de uma escola municipal de Ilhéus (BA). Halmenschlager et al. (2017) e Bernardi et al. (2015) articulam a abordagem temática freireana com o estágio à docência. Alves e Silva (2015), a partir das "situações-limites", apontam obstáculos gnosiológicos para a construção de currículos críticos de ciências manifesto por professores da rede pública de Sorocaba-SP. Já Saul e Saul (2017) buscam na investigação temática os fundamentos político-epistemológicos da práxis de pesquisa crítico-emancipatória. No sentido da organização curricular a partir da abordagem temática freireana no ensino de ciências, Demartini $(2015,2017)$, Demartini e Silva (2016) e Furlan et al. (2011) elaboraram a organização programática via temas geradores. Entretanto, tais trabalhos não enfatizam as contribuições da abordagem de temas dobradiças no processo de investigação temática.

Algumas importantes contribuições são construídas por Silva $(2004,2007)$, como parte do processo de investigação temática realizado em diversas escolas públicas do País. Buscando a coerência com a exigência epistemológica freireana de dialogicidade para a construção de uma práxis curricular ético-crítica, isto é, comprometida com a libertação dos oprimidos, desenvolve os conceitos teórico-metodológicos de "fala significativa", "rede temática" e "contratema" além da organização do percurso de construção do currículo. Neste sentido, Sousa et al., 2014) organiza os momentos da Práxis Curricular via Tema gerador elaborada por Silva (2004). 
I) Momento: relacionado à problematização da prática pedagógica vigente na comunidade escolar;

II) Momento: busca das situações-limite a partir das falas da comunidade que serão problematizadas em sala de aula para obtenção do Tema gerador;

III) Momento: construção de uma Rede Temática a partir da qual relacionamse as visões de mundo da comunidade e dos educandos (Tema gerador) e a compreensão dos educadores (Contratema), permitindo a identificação dos conceitos unificadores;

IV) Momento: construção de questões geradoras a partir do Tema/Contratema e com isso a elaboração do conteúdo programático;

V) Momento: que corresponde a reorganização coletiva da escola a partir do fazer pedagógico (Sousa et al., 2014, p. 3).

Fundamentando-se no conceito de "situações-limites" de Freire (1987), as "falas significativas" possibilitam acessos às visões de mundo em que se encontram expressos os Temas Geradores. Enquanto Freire comumente representava as "situaçõeslimites" por meio de recursos pictóricos, as "falas significativas" apresentam-se por meio de vocalizações que expressam visões reducionistas da concretude do real, e por isso necessitam de problematizações. Em síntese, são vocalizações que exprimem a incapacidade de ser sujeito na (re)construção do mundo, são exteriorizações que evidenciam a negação do protagonismo da práxis transformadora e a não percepção da realidade concreta em sua totalidade (Silva, 2004).

Se o tema gerador, manifestando as negatividades presentes na visão de mundo da comunidade, torna-se o ponto de partida da sistematização curricular, o ponto de chegada da prática pedagógica recebe o nome de "contratema" e expressa uma compreensão em totalidade da realidade concreta, organizado intencionalmente para promover com os educandos o desvelamento das contradições socioculturais presentes. A inserção deste ponto de ancoragem respeita uma compreensão dialógica e dialética na práxis curricular (Silva, 2004). De acordo com Silva (2004),

[...] todo tema traz, dialeticamente, um 'contratema' implícito ou explícito. Da sua consciência e clareza dependerá o sentido programático que se pretende construir. Se podemos considerar o tema como ponto de partida pedagógico, o 'contratema' seria uma bússola norteadora da síntese analítica/propositiva, desveladora da realidade local que se pretende construir com os educandos (pp. 199-200).

Já as "redes temáticas", como produção coletiva, são expressões das relações socioculturais de um contexto. Representadas graficamente, auxiliam o processo de construção da programação curricular por articularem as falas significativas em uma 
totalização concreta - desde dimensões locais, micro e macrossociais, passando pela consideração de aspectos socioculturais, econômicos, infraestruturais, geográficos, ambientais etc. A partir de movimentos dedutivos e indutivos, possibilita um distanciamento analítico fundamental para a práxis curricular (Silva, 2004).

Para construir uma rede realiza-se, inicialmente, uma sistematização das análises relacionais percebidas nas falas significativas da comunidade presentes no levantamento preliminar. Tais relações, bem como o tema gerador selecionado, são representadas na base da rede temática. [...]. Uma segunda parte da rede é construída propondo as relações entre os elementos da organização social que os educadores envolvidos no projeto qualificam como as mais consistentes para analisar os problemas locais. Parte-se então dos nexos pertinentes à localidade para uma dimensão micro, e desta para a representação macrossocial, buscando explicitar as relações socioculturais e socioeconômicas nos diferentes níveis. (p. 220).

Para Silva (2004), o que se pretende, “[...] é partir das Falas Significativas e chegar a práticas contextualizadas, ou seja, sistematizar uma racionalidade problematizadora para a construção de um currículo popular crítico" (p. 163).

Delizoicov et al. (2011) propõem outra contribuição para o processo de reorientação da investigação temática para o ensino de ciências no universo escolar, caracterizando a abordagem temática freireana em cinco etapas sistematizadas: (1) Levantamento Preliminar - trata-se da caracterização do contexto sociocultural da comunidade; (2) Análise das Situações e Escolha das Codificações — trata-se da obtenção das "situações-limites"; (3) Diálogos Descodificadores - trata-se da problematização e desvelamento das contradições socioculturais presentes nas "situações-limites" e no tema gerador; (4) Redução Temática - trata-se da elaboração da programação curricular/ seleção dos conteúdos sociocientíficos necessários para a compreensão rigorosa e crítica da realidade; (5) Trabalho em Sala de Aula — trata-se da dinâmica dialógica em sala de aula.

Por fim, como possibilidade de construção de uma prática docente, em sala de aula, com correspondência com a epistemologia dialógica freireana Delizoicov et al. (2011) apresentam os seguintes momentos pedagógicos: Problematização Inicial, em que os alunos são desafiados em suas visões de mundo; Organização do Conhecimento, estágio em que o conhecimento científico é contemplado e Aplicação do Conhecimento, que envolve o uso praxiológico do conhecimento apreendido.

Todas as contribuições à investigação temática - não tivemos a pretensão de esgotá-las quantitativa e qualitativamente - respeitam o fundamento epistemológico marcante da pedagogia libertadora, a dialogicidade. Afinal, o que é o diálogo? É a leitura crítica, problematizadora e transformadora da realidade, das suas negatividades, a partir 
da fala do Outro (Dussel, 2000), da vítima que se reconhece e luta por sua libertação. O que o diálogo não é? Não é qualquer conversa, não é um devaneio, não é uma mistificação ideológica e nem uma imposição. Assim, evidencia-se como o processo dialógico freireano possibilita fundamentos para o exercício da práxis autêntica. Tratase, na pedagogia libertadora, de uma busca pela racionalidade curricular ético-crítica.

\section{Metodologia}

Devido à natureza do problema de pesquisa, procura-se suporte numa metodologia de pesquisa qualitativa, pois, compreende-se que o mundo é uma construção social, histórica, em movimento dialético, circunscrito pelas representações dos agentes nele presente. A compreensão dos fenômenos educativos, que são concretos, exige uma descrição e interpretação dos fatos que revele os significados conferidos pelos sujeitos, buscando as raízes destes e as causas de sua existência, suas relações sociais e suas transformações históricas (Triviños, 1987). O método empregado nesta pesquisa é do tipo pesquisa-ação, pois, procura-se desenvolver o conhecimento e a compreensão da realidade como parte da prática, ao mesmo tempo em que se pretende a transformação. Trata se de uma opção pela não neutralidade da educação, do conhecimento, do pesquisador e pela leitura crítica da realidade social, passando obrigatoriamente pela práxis do grupo social em questão (Barbier, 1985; Thiollent, 1986).

Neste sentido, na disciplina de Biologia em uma escola estadual do Município de São Francisco do Brejão (MA), buscou-se desenvolver o processo de construção curricular local por meio da investigação temática (Freire, 1987), aqui caracterizada como abordagem temática freireana (Delizoicov et al., 2011). Primeiramente, realizouse a caracterização do contexto local: documentos oficiais, regimentos escolares, plano político pedagógico, livros sobre o Município, relatos e observações de campo foram utilizados. Durante as atividades pedagógicas em sala de aula, foram obtidas falas significativas que nortearam a construção da rede temática (Silva, 2004) - destacamos que durante o processo, quinze estudantes se manifestaram. Uma programação curricular foi proposta a partir da rede temática elaborada. Por fim, a partir de um "tema dobradiça" identificado, e de novas problematizações uma mobilização social foi articulada no sentido de promover uma transformação concreta na realidade local com a construção de uma quadra de vôlei de areia. Em decorrência da limitação espacial, este trabalho não traz a implementação em sala de aula da programação construída. Aqui cabe destacar que se trata da prática pedagógica de um educador da rede pública do estado do Maranhão em busca de promover uma práxis curricular autêntica (Freire, 1987), não sendo, portanto, desenvolvida como objeto de uma pesquisa acadêmica a priori.

Ressaltamos que, com base nas contribuições da análise crítica do discurso (Fairclough, 2001), em coerência com a perspectiva do materialismo histórico dialético, foram considerados os discursos a partir das contradições sociais explicitadas pelas falas significativas (Silva, 2004). Neste sentido, buscou-se problematizar dialeticamente as 
contradições em movimentos indutivos e dedutivos, no exame de suas relações entre as partes e a totalidade sociocultural, com vistas à seleção de conhecimentos científicos fundamentais para a superação dos limites expressos.

Cabe destacar que todas as falas significativas foram coletadas durante a rotina das atividades pedagógicas em sala de aula. A partir de dinâmicas problematizadoras, de modo coletivo e não individualizado, preservou-se eticamente o anonimato dos sujeitos e manteve-se de acordo os fundamentos políticos e epistemológicos da pesquisa-ação (Barbier, 1985; Thiollent, 1986). Refere-se, portanto, à descrição do cotidiano curricular desenvolvido ao longo de uma programação formal do ensino médio, não se tratando de entrevistas ou de questionários investigativos.

Portanto, a investigação temática iniciou-se com uma importante etapa, a caracterização da realidade local que possibilita a compreensão ampla e relacional de dimensões socioeconômicas, históricas, ambientais e culturais do local de interesse. A realidade em questão é São Francisco do Brejão, uma cidade do oeste maranhense que conquistou sua fundação somente em 1994. Localizada entre as cidades de Imperatriz e Açailândia, foi colonizada por lavradores baianos no final da década de 1960 (Vale, 2012). Com população estimada em 11.700 habitantes (Instituto Brasileiro de Geografia e Estatística - IBGE, 2019), a cidade divide-se entre o núcleo urbano principal e diversos vilarejos rurais.

A cidade é conhecida como "Brejão", o que referencia características de sua vegetação, hidrografia, terreno e clima. Como parte do bioma amazônico, grandes áreas florestais pertenceram ao seu território, hoje na maior parte desmatado pela atividade pecuária. Apesar disso, a riqueza biológica e hídrica da região ainda é expressiva. Em comum a outras regiões do País, a desigualdade social é evidente e causa de inúmeros problemas sociais.

Sua economia está baseada principalmente na agropecuária, o que a torna uma importante bacia leiteira do Estado. Por isso, significativa parte dos empregos gerados no município advém de fazendas e laticínios, mas também do comércio local e do serviço público (Vale, 2012). A questão do trabalho é um fator limitante para os jovens que encontram grande dificuldade de inserção no mercado de trabalho.

Trata-se de um Município convidativo e acolhedor, mas em que pese seu modo de vida pacato e a exuberância da beleza local, apresenta sequelas de políticas públicas irresponsáveis que historicamente relegaram à expressiva parte da população precárias condições de urbanização, trabalho, habitação, alimentação, atendimento à saúde e cultura. Segundo dados do IBGE, São Francisco do Brejão,

Apresenta 8.6\% de domicílios com esgotamento sanitário adequado, 80.4\% de domicílios urbanos em vias públicas com arborização e $0 \%$ de domicílios urbanos em vias públicas com urbanização adequada (presença de bueiro, calçada, pavimentação e meio-fio). Quando comparado com os outros municípios do estado, fica na posição 103 de 217, 57 de 217 e 139 de 217, respectivamente. Já quando comparado a outras cidades do Brasil, sua posição é 4484 de 5570, 
2371 de 5570 e 4835 de 5570, respectivamente (Instituto Brasileiro de Geografia e Estatística - IBGE, 2019).

Na cultura local há forte influência do modo de vida rural, sobretudo da figura do vaqueiro e do fazendeiro que aparecem no imaginário popular. Segundo dados do IBGE, na dimensão religiosa o Município apresenta maioria católica, mas com expressiva participação das igrejas evangélicas. Outras vertentes como espiritismo e umbanda estão presentes no Município, mas com baixa adesão.

O sistema educacional local foi estruturado a partir da mobilização dos professores que durante muitos anos enfrentaram problemas como falta de estrutura predial e apoio governamental. Com apenas uma escola de ensino médio - C.E.M. Tobias Barreto, com uma sede no núcleo urbano principal e um anexo distante 20 quilômetros no vilarejo Trecho Seco, às margens da BR-010 - atende aproximadamente 320 estudantes na sede, nos períodos matutino e noturno. Seu corpo docente e gestão escolar apresentam aproximadamente 20 pessoas que, com muita engenhosidade e dedicação lidam com problemas de evasão, abandono escolar e escassez de recursos.

Esta breve descrição do contexto possibilita uma visão panorâmica da cidade e da comunidade escolar, além de auxiliar no movimento posterior de construção do processo de investigação temática representado na rede temática.

\section{A escuta do outro como ponto de partida para o diálogo}

Após a caracterização da realidade local, as atividades pedagógicas realizadas com os educandos na disciplina de Biologia, possibilitaram identificar nas suas expressões discursivas alguns limites na compreensão da realidade. Essas manifestações expressam "situações-limites" (Freire, 1987) constituindo "falas significativas" (Silva, 2004), elementos fundamentais para a identificação de "temas geradores", e para a realização do processo de redução temática representado por uma rede de relações — "rede temática" para Silva (2004). Como anteriormente mencionado, as falas significativas se caracterizam pela presença de contradições percebidas pelos educadores na visão de mundo dos educandos, coerentemente com a metodologia proposta por Fairclough (2001) na análise crítica do discurso. Tais contradições socioculturais, muitas vezes são denominadas "situações-limites" (Freire, 1987) como é o caso de Silva et al. (2016) e Silva e Gehlen, (2016). Em outros trabalhos, como Lamback (2013) e Saul (2015), partem-se da caracterização de falas significativas como expressões de contradições e desenvolvem sua pesquisa no contexto de formação permanente de professores.

Ressalta-se que as contradições socioculturais podem aparecer nos discursos como manifestações de alienação, de fatalismos, como negação dos sujeitos históricos, como distanciamento da realidade concreta em submissão às dimensões transcendentais. Enfim, todas como expressões de barreiras à realização ontológica do ser humano, como obstáculos ao Ser Mais (Freire, 1987).

Nesse sentido, a Figura 1 descreve falas significativas selecionadas e possíveis contradições socioculturais identificadas. 
Figura 1. Algumas das falas significativas obtidas e suas respectivas possíveis contradições socioculturais

\begin{tabular}{|c|c|}
\hline Fala Significativa & Possíveis contradições socioculturais \\
\hline $\begin{array}{l}\text { 1. "Deus trilhou o meu caminho, dele não } \\
\text { posso sair". }\end{array}$ & $\begin{array}{l}\text { Há uma transferência da responsabilidade dos rumos } \\
\text { da vida para a transcendência. Acomodação. Alienação. } \\
\text { Compreensão fatalista, inerte, imutável da realidade } \\
\text { concreta estabelecida. Em um contexto de evidentes } \\
\text { injustiças sociais, esta compreensão subserviente permite } \\
\text { a manutenção da opressão e consequente desumanização. }\end{array}$ \\
\hline $\begin{array}{l}\text { 2. "Às vezes penso que minha vida é difícil, } \\
\text { muita dificuldade financeira, mas aí eu } \\
\text { me lembro de que se está acontecendo é } \\
\text { porque Deus quer e só ele sabe o que é } \\
\text { melhor para nós". }\end{array}$ & $\begin{array}{l}\text { Alienação da capacidade de ser dono da própria } \\
\text { história. Visão fragmentada e reducionista dos motivos } \\
\text { das injustiças, que sequer são percebidas assim. } \\
\text { Compreensão fatalista, inerte, imutável da realidade } \\
\text { concreta estabelecida. Atribuição da dificuldade } \\
\text { financeira à transcendentalidade. Tal atitude embebida } \\
\text { de conformismo impede a compreensão na totalidade das } \\
\text { dimensões que envolvem a produção da miséria concreta. }\end{array}$ \\
\hline $\begin{array}{l}\text { 3. "Não digo que passamos fome, mas } \\
\text { agente come bem quando tem o que } \\
\text { comer. Não tem comida ruim, ruim é não } \\
\text { ter o que comer. Quando Deus permite, } \\
\text { agente come bem." }\end{array}$ & $\begin{array}{l}\text { Compreensão fatalista, inerte, imutável da realidade } \\
\text { concreta estabelecida. Atribuição da dificuldade em se } \\
\text { alimentar à transcendentalidade. Tal atitude impede a } \\
\text { compreensão na totalidade das dimensões que envolvem } \\
\text { a produção da miséria concreta. }\end{array}$ \\
\hline $\begin{array}{l}\text { 4. "Sou uma pessoa humilde, por isso não } \\
\text { gosto de muita mudança". }\end{array}$ & $\begin{array}{l}\text { O movimento e a transformação são negados como } \\
\text { possibilidade ao sujeito humilde. Compreensão fatalista. } \\
\text { Atribuição do caráter imutável da realidade concreta } \\
\text { estabelecida à simplicidade. Possível medo da liberdade. } \\
\text { Expressão da negação ontológica do ser humano } \\
\text { que, coisificado, deixa de ser reconhecido pela práxis } \\
\text { transformadora. }\end{array}$ \\
\hline $\begin{array}{l}\text { 5. "Tendo arroz, feijão e farinha, vivo } \\
\text { sem fome. Está bom demais, não precisa } \\
\text { mais que isso." }\end{array}$ & $\begin{array}{l}\text { Incompreensão das necessidades orgânicas alimentares. } \\
\text { Não percepção da insuficiência do quadro alimentar } \\
\text { descrito, bem como demasiado conformismo. Análise } \\
\text { simplista que não atinge a estrutura injusta produtora da } \\
\text { desigualdade social. }\end{array}$ \\
\hline $\begin{array}{l}\text { 6. "Não sei por que estudar tanto. Acabar } \\
\text { a escola pra que? Não tem emprego nessa } \\
\text { cidade. Haja roça de juquira prá todo } \\
\text { mundo." }\end{array}$ & $\begin{array}{l}\text { Sofrimento juvenil diante das escassas oportunidades } \\
\text { de inserção profissional no mercado. Compreensão } \\
\text { pragmática da educação escolar que leva, diante de um } \\
\text { quadro de baixa perspectiva de trabalho, ao abandono } \\
\text { das atividades escolares. }\end{array}$ \\
\hline $\begin{array}{l}\text { 7. "Aqui agente trabalha com hora prá } \\
\text { entrar sem hora pra sair, todo santo } \\
\text { dia. O ganho é pouco, mas ainda bem } \\
\text { que Deus nos dá patrões bons prá dar } \\
\text { trabalho." }\end{array}$ & $\begin{array}{l}\text { Não compreensão do conflito inevitável entre os interesses } \\
\text { do patrão e os interesses do trabalhador. Compreensão } \\
\text { fatalista, subserviente, inerte, imutável da realidade } \\
\text { concreta estabelecida. Naturalização do descumprimento } \\
\text { das leis trabalhistas. }\end{array}$ \\
\hline
\end{tabular}

Fonte: Adaptado a partir de Demartini (2017). 
A análise das contradições socioculturais presentes nas falas significativas obtidas possibilita a percepção, presente na visão de mundo dos educandos, da incapacidade de posicionar-se como sujeitos da sua própria história, com isso relega-se à transcendência a responsabilidade pela concretude da vida social (Falas 1, 2, 3, 4, 7). Trata-se de uma negação da assunção do sujeito como protagonista de sua própria história, que se realiza enquanto tal a partir de sua atividade criativa e transformadora, à medida que busca a produção da sua existência (Freire, 1987). Há também manifestações que demonstram a acomodação diante da escassez e das injustas relações de expropriação do trabalho (Falas 3, 5, 6, 7).

Mas, no conjunto de falas coletadas, uma especificamente apresenta-se como o tema gerador. A referida fala: "Sou uma pessoa humilde, por isso não gosto de muita mudança". Ao apresentar as contradições mais amplas - que evidenciam uma posição fatalista da realidade que, apresentando-se incapaz de mudar, impede a realização ontológica do ser humano como ser da práxis autêntica, relacionando isso com a "humildade" de alguém que sabe o seu lugar num contexto de "cultura do silêncio" engloba as demais falas significativas e apresenta-se como o tema gerador, a partir do qual a rede temática deve se organizar para a construção da programação curricular.

Na perspectiva curricular freireana, a problematização está envolvida pela exigência epistemológica de dialogicidade e mostra-se como fundamento para a "descodificação" coletiva da realidade concreta. Trata-se de uma nova compreensão que não se esgota na tomada de consciência, mas ganha corpo em uma ação transformadora. Ou seja, pelo questionamento da naturalização de injustiças socioculturais, pelo desvelamento das formas de opressão construídas e tomadas como instransponíveis, pela compreensão crítica das origens das negatividades produzidas nas relações entre os homens e desde com o mundo, pode-se recuperar o sonho e a esperança - a dimensão ontológica - de reassumir-se como sujeito de sua própria história à medida que se orienta para a práxis autêntica (Freire, 1987). Para Freire (1987),

Se as massas populares dominadas, por todas as considerações já feitas, se acham incapazes, num certo momento histórico, de atender a sua vocação de ser sujeito, será, pela problematização de sua própria opressão, que implica sempre numa forma qualquer de ação, que elas poderão fazê-lo (p. 96).

Uma vez esclarecida a importância da problematização/descodificação, as falas significativas e o tema gerador foram discutidos com os educandos - o que Freire (1987) denomina de círculo de investigação temática. Buscou-se assim, atingir o distanciamento analítico necessário para o entendimento rigoroso das contradições socioculturais, resgatando a compreensão em totalidade da realidade concreta, além da proposição de elementos contextualizados para a rede temática (Silva, 2004).

Desta maneira, as dimensões significativas que, por sua vez, estão constituídas de partes em interação, ao serem analisadas, devem ser percebidas pelos indivíduos como dimensões da totalidade. Deste modo, a análise crítica de uma dimensão 
significativo-existencial possibilita aos indivíduos uma nova postura, também crítica, em face das "situações-limites". A captação e a compreensão da realidade se refazem, ganhando um nível que até então não tinham. Os homens tendem a perceber que sua compreensão e que a "razão" da realidade não estão fora dela, como, por sua vez, ela não se encontra deles dicotomizada, como se fosse um mundo à parte, misterioso e estranho, que os esmagasse (Freire, 1987, p. 55).

Nesse sentido, Silva (2004) sistematiza esse processo de contextualização a partir do tratamento de diferentes dimensões da realidade. Primeiramente em uma dimensão local, depois micro/macro, e por fim novamente na dimensão local, porém agora de forma propositiva. A síntese desse movimento encontra-se na Figura 2.

Figura 2. Problematização do tema gerador

\begin{tabular}{|c|c|}
\hline Problematização do tema gerador: "Sou uma pessoa humilde, por isso não gosto de muita \\
mudança".
\end{tabular}

\section{Problematização Local}

O que faz uma pessoa ser humilde? Por que a mudança não combina com uma pessoa humilde? Toda imobilidade é boa? Toda mudança é ruim? Quando uma mudança pode ser ruim e quando pode ser boa? A mudança remete ao sentimento de medo ou de coragem, ao sentimento de culpa ou ambição por realizar-se? É importante ter espaços para falar sobre as condições da vida concreta?

\section{Problematização Micro/Macro}

As condições de vida são boas para todos no Brejão? O que dificulta ou impede uma vida digna para todos? Nesta realidade a quem interessa a imobilidade e a perpetuação da desigualdade? Isso é ético e justo? A mudança é necessária? A quem cabe esta mudança, isto é, quem pode e deve fazê-la? Nesta dinâmica, qual é o papel da escola? Qual é o papel da religião? Qual é o papel das políticas públicas? É necessário que exista participação popular? É possível a mudança social sem mobilização coletiva?

Como o domínio político-econômico e a propriedade privada dos meios de produção impedem essa mudança? Quais interesses entrariam em conflito com uma mudança? Como uma cultura da inação, uma cultura do silêncio mantém a injustiça social?

\section{Problematização Local (Proposição)}

Como podemos superar a inação, a passividade, que nega ontologicamente os seres humanos e nos posicionarmos como cidadãos, como sujeitos da história? Como retomar as rédeas do desenvolvimento da vida coletiva? Como superar uma posição de subserviência e acomodação às coisas como elas estão?

Como associações de bairro, ONGs, sindicatos, movimentos educacionais, religiosos, entre outros, podem atuar representando os interesses populares diante da elite política e econômica da cidade? Que alternativas podem ser criadas? As medidas precisam dar-se em âmbito individual ou coletivo? Por quê?

Em que medida a participação popular, isto é, o povo, com sua voz, organizado em torno do enfrentamento de sua condição concreta de vida, desumana, pode efetivar uma transformação social? Uma transformação sociocultural necessitaria de que tipo de cultura de comunicação, em que espaços, de que formas? Como tornar essas possibilidades reais?

Fonte: Adaptado a partir de Demartini (2017). 


\section{Do contexto à construção da Rede Temática}

A elaboração da rede temática (Figura 3) se deu a partir das falas significativas, do tema gerador e de sua problematização. Em sua estrutura, a rede buscou salvaguardar em diferentes amplitudes, as diversas relações socioculturais presentes no contexto local. Assim, com a visão de totalidade, possibilitou movimentos indutivos/dedutivos na análise do contexto, favorecendo a problematização profunda das contradições socioculturais. Neste sentido, criou condições para o processo de "redução temática", ou seja, para a seleção do conteúdo programático.

Mas há algo a se ressaltar na construção da rede temática. Embora a organização curricular tenha como eixo as contradições socioculturais expressas na visão de mundo dos educandos, de forma dialógica a visão docente também é incorporada como objetivo a ser atingido pela prática pedagógica.

É a apreensão do significado e interpretação dos temas por parte dos alunos que precisar estar garantida no processo didático-pedagógico, para que os significados e interpretações dados possam ser problematizados. Porém, na perspectiva de uma educação dialógica, como a proposta por Freire, os significados e interpretações dos temas pelos alunos não serão os únicos que terão de ser apreendidos e problematizados; aqueles que o professor é portador também precisam estar presentes no processo educativo (Delizoicov et al., 2011, p. 193).

Neste sentido, Freire (1987) deixou indicativos de que os temas identificados em um contexto estão em interação dialética com os seus contrários.

Uma unidade epocal se caracteriza pelo conjunto de ideias, de concepções, esperanças, dúvidas, valores, desafios, em interação dialética com seus contrários, buscando plenitude. A representação concreta de muitas destas ideias, destes valores, destas concepções e esperanças, como também os obstáculos ao ser mais dos homens, constituem os temas da época. Estes, não somente implicam em outros que são seus contrários, às vezes antagônicos, mas também indicam tarefas a ser realizadas e cumpridas. Desta forma, não há, como surpreender os temas históricos isolados, soltos, desconectados, coisificados, parados, mas em relação dialética com outros, seus opostos. Como também não há outro lugar para encontrá-los que não seja nas relações homens-mundo. $\mathrm{O}$ conjunto dos temas em interação constitui o "universo temático" da época (p. 53). 
Figura 3. Rede Temática de São Francisco do Brejão

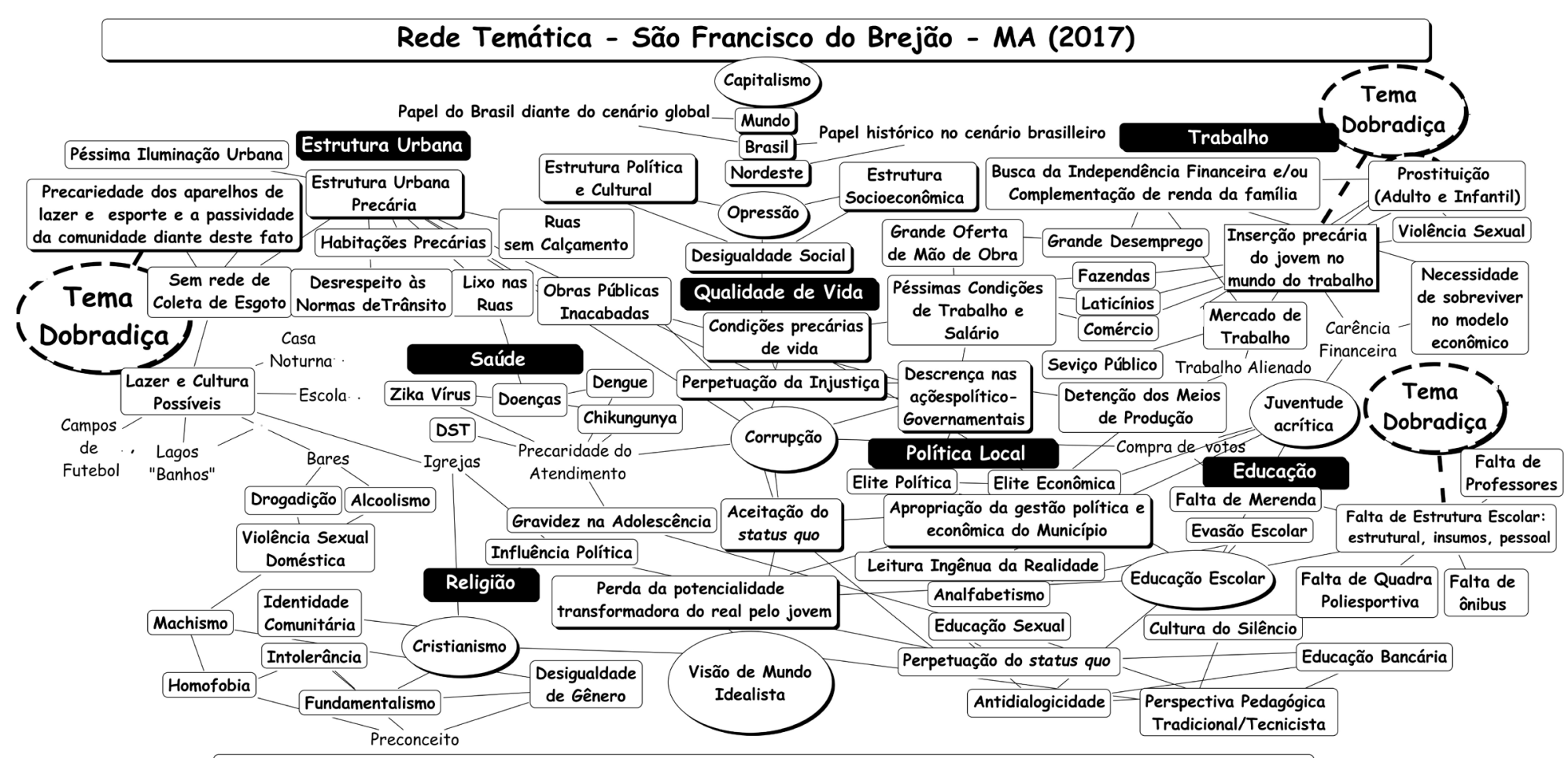

Contratema: Resgatando a dimensão transformadora da existência humana: sujeitos na produção da existência coletiva

Tema Gerador: "Sou uma pessoa humilde, por isso não gosto de muita mudança"

\section{Conformismo}

"O que Deus fez e quer não se muda".

"Deus trilhou o meu caminho, dele não posso sair".

"Mudaria poucas coisas na minha vida, mas quem sou eu para mudar alguma coisa."

"Não desgosto de nada na minha vida, pois, devemos sempre agradecer pelo que temos".

"Não mudaria nada porque tudo está bem do jeito que está Se é pra ser assim, pra que mudar?".

"Tudo o que temos e conquistamos é presente de Deus. Se as coisas são dadas por Deus não precisamos mudar nada" "Não mudaria nada, pois, tudo o que acontece não é em vão. Se nós mudarmos o presente, podemos afetar um futuro que já está destinado".

"Gostaria que as coisas melhorassem, mas para isso acontecer eu entrego nas mãos de Deus. Ele é o único que pode me dar forças para prosseguir".

"Não é muito fácil a vida, há muitas dificuldades nessa cidade, até para chegar na escola, mas gosto dessa vida porque foi a que Deus escolheu pra mim".

"Às vezes penso que minha vida é difícil, muita dificuldade financeira, mas aí eu me lembro de que se está acontecendo é porque Deus quer e só ele sabe o que é melhor para nós". Política

"Eles [Políticos] roubam agente por quatro anos quando entram pelo menos agora vamos roubar eles um pouco também [sobre receber dinheiro para merenda em troca da promessa de voto]

\section{Esporte e Lazer}

"Aqui se você não gosta de futebol não tem o que fazer não. Bicicleta nem todos têm. $O$ jeito é arrumar um celular."

"Falta incentivo do governo, tem tanta criança na rua e sem espaço pra se divertir, mas isso sempre foi assim mesmo".

"Nessa cidade não tem nada pra fazer, ou é igreja ou é bar, quem tem dinheiro pode ir para Imperatriz ou Açailândia."

"No campo de futebol nem todos podem jogar, temos que esperar ficar mais velhos prá jogar, na quadra nova é

tanta gente que ninguém joga mais que 5 minutos. $O$ jeito é inventar na rua mesmo."

"Esse lugar aqui sempre foi assim. Começam a construir as quadras, mas as empresas não pagam os funcionários aí a obra para. Alguém está pegando esse dinheiro e nós ficamos sem lugar pra jogar".

$$
\text { Trabalho }
$$

"Não faço a menor ideia do que fazer no futuro. Não tem emprego nessa cidade, e o que tem é muita exploração. Não tem solução, tem que mudar da cidade."

"Aqui a gente trabalha com hora prá entrar sem hora prá sair, todo santo dia. $O$ ganho é pouco, mas ainda bem que Deus nos dá patrões bons pra dar trabalho."

"Não sei por que estudar tanto.

Acabar a escola pra que? Não tem emprego nessa cidade. Haja roça de juquira prá todo mundo."
Sexualidade e Gênero

"O Pastor disse que as crianças vão ter que usar o mesmo banheiro". ["Ideologia de Gênero"]

"Estão querendo fazer nossas crianças virarem homossexuais, e chamam isso de educação sexual".

"Não aguento mais trabalhar, todo dia a mesma coisa, devia ter nascido homem pra não ter que arrumar a casa".

"Meu relacionamento [marido e mulher] não tem diálogo,e é ruim ser dependente, mas Deus é maior, um dia ele há de ter compaixão de mim".

"É um absurdo ensinarem sobre essas coisas [sexualidade] na escola, outro dia meu filho chegou falando que sabia que viemos do espermatozoide. A escola deveria ensinar a ler. escrever e fazer conta."

Alimentação / merenda

"Tendo arroz, feijão e farinha, vivo sem fome.Está bom de mais, não precisa mais que isso."

"Trocaria a janela de vidro da escola por merenda. Eu não preciso do vidro para aprender, mas de comida preciso."

"Estudar que jeito? Com tanta fome [devido a ausência de merenda] você só pensa em ir embora, até dói a barriga. Fazer o que é assim, a vida não é fácil."

"Não digo que passamos fome, mas a gente come bem quando tem o que comer. Não tem comida ruim, ruim é não ter o que comer. Quando Deus permite, a gente come."

Fonte: Adaptado a partir de Demartini (2017). 
Neste sentido, o "contratema" formulado enquanto visão docente sistemática, como negação da negatividade presente nas contradições socioculturais, pode ser caracterizado da seguinte forma: "Resgatando a dimensão transformadora da existência humana: sujeitos na produção da existência coletiva". Assim, representa o horizonte político e ético-crítico do processo educativo, o ponto de chegada da prática educacional formulado em resposta às contradições socioculturais e sinaliza o respeito a uma compreensão materialista-dialética da leitura da realidade no processo políticoepistemológico.

Por fim, embora a rede possua uma espinha dorsal que sustente o tema gerador, há outras possibilidades importantes na estrutura da rede que aparecem de forma marginal, mas merecem atenção, pois inseridos pela visão docente, são fundamentais para a compreensão crítica do tema gerador. Trata-se dos temas dobradiças (Freire, 1987), por exemplo: a precariedade dos aparelhos de lazer e esporte e a passividade da comunidade diante deste fato; a falta de estrutura física e insumos básicos para o sistema educacional; a inserção precária do jovem no mundo do trabalho, entre outros.

\section{Da contextualização crítica da realidade à práxis curricular}

Com o apoio da rede temática deu-se a dinâmica de escolha dos conteúdos científicos necessários para a compreensão das contradições socioculturais, culminando na proposição de uma programação curricular para a disciplina de Biologia. A partir das contradições presentes em cada fala significativa e da listagem dos conteúdos das diferentes áreas da ciência para a sua compreensão, um esboço da programação curricular foi elaborado.

Neste momento de redução temática cabe aos profissionais da educação, dialogando com a realidade concreta, definir os conteúdos específicos. Por isso, Freire (1987) aponta que,

Feita a delimitação temática, caberá a cada especialista, dentro de seu campo, apresentar à equipe interdisciplinar o projeto de "redução" de seu tema. No processo de "redução" deste, o especialista busca os seus núcleos fundamentais que, constituindo-se em unidades de aprendizagem e estabelecendo uma sequência entre si, dão a visão geral do tema "reduzido". Na discussão de cada projeto específico, se vão anotando as sugestões dos vários especialistas. Estas, ora se incorporam à "redução" em elaboração, ora constarão dos pequenos ensaios a serem escritos sobre o tema "reduzido", ora uma coisa e outra (p. 66).

A programação construída é relativa ao contexto local, sem neste se limitar; é produto coletivo da práxis educativa realizada na escola. Uma pequena parte da programação construída está expressa na Figura 4. 
Figura 4. Recorte da Programação Curricular Construída

\section{$1^{\circ}$ ano do Ensino Médio \\ Fala Significativa}

“Tendo arroz, feijão e farinha, vivo sem fome. Tá bom demais, não precisa mais que isso.”

- Por que necessitamos de alimentos? Relação dos produtos consumidos com as necessidades energéticas e nutricionais.

- Qual é a alimentação real e qual é a alimentação ideal? No cotidiano, o que comemos? Pirâmide Alimentar Real e Pirâmide alimentar a partir dos produtos da terra local, levantados em feira ocorrida no município.

- Bioquímica das moléculas orgânicas: Carboidratos, Lipídios, Proteínas, Vitaminas, Sais Minerais.

- Alimentação Equilibrada e alimentação desequilibrada. Transtornos Alimentares.

- Relação da nutrição com o sistema imunológico. Fisiologia e Anatomia do Sistema Digestório.

- Falta de Acesso a alimentos. Mas é direito constitucional? Documentário sobre a fome. Resgate histórico da fome no Maranhão e Nordeste. Mapa da fome no mundo, no Brasil, no Maranhão e na cidade.

- A fome é uma realidade no Brejão? Se estamos numa região de grande riqueza vegetal e hídrica, por que isso ocorre?

- O que interfere na produção e distribuição dos alimentos? Clima, Economia, Mercado, Logística.

- Impacto da alimentação deficiente no desenvolvimento corporal, cognitivo e educacional.

- Conceito de Segurança Alimentar.

- Mecanismos de distribuição de renda - bolsa família.

- Enfrentamento à fome- políticas públicas locais (Secretaria Municipal de Assistência Social).

- O problema da falta de merenda escolar - estabelecendo diálogo com o setor público municipal.

- Construção de horta comunitária - Comunidade alimentando a transformação local.

Fonte: Adaptado a partir de Demartini (2017).

Numa primeira impressão o tema gerador pode não sugerir uma conexão instantânea com a área das ciências biológicas, porém a aproximação a partir dos seus meandros permite a visualização que diferentes áreas podem contribuir para a compreensão das negatividades presentes nas contradições. Isso porque compartilham um arranjo sociocultural da qual a interpretação sistemática não pode prescindir da contribuição dos diferentes campos da Ciência.

Essas contribuições das diversas áreas vem a partir das demandas interpretativas e conceituais que acompanham o tema gerador e as falas significativas, mas também em função das subtemáticas complementares que, adicionadas pela visão docente, possibilitam a compreensão em totalidade. Esses temas Freire (1987) chama de Temas Dobradiças. 


\section{Demandas epistemológicas: a relevância do tema dobradiça na construção curricular}

Além do tema gerador, da rede temática, do contratema e da programação construída, um tema dobradiça importante para compreender os limites expressos foi identificado, a saber: "a ausência dos aparelhos urbanos de lazer e esporte e a passividade da comunidade diante deste fato", que diante de uma realidade caracterizada pela desigualdade social, pela marginalização dos jovens pelas políticas públicas, pela grande dificuldade de inserção no mercado de trabalho, assume singular importância. Novas manifestações, agora de cinco educandos trazendo este tema para o debate, permitiram a captação de algumas falas significativas (Figura 5).

Figura 5. Falas significativas e suas contradições socioculturais.

\begin{tabular}{|c|c|}
\hline Falas Significativas & Possíveis contradições socioculturais \\
\hline $\begin{array}{l}\text { "Nessa cidade não tem nada pra fazer, ou é } \\
\text { igreja ou é bar, quem tem dinheiro pode ir para } \\
\text { Imperatriz ou Açailândia." }\end{array}$ & $\begin{array}{l}\text { - Limitação das alternativas de lazer e esporte } \\
\text { na cidade. } \\
\text { - Dinheiro como fator de exclusão, pois é } \\
\text { condição para acesso a cultura ou lazer em } \\
\text { outra cidade. }\end{array}$ \\
\hline $\begin{array}{l}\text { "Falta incentivo do governo, tem tanta criança na } \\
\text { rua e sem espaço pra se divertir, mas isso sempre } \\
\text { foi assim mesmo". }\end{array}$ & $\begin{array}{l}\text { - Aceitação passiva diante da negligência do } \\
\text { governo municipal com relação à oferta de } \\
\text { espaços de lazer e cultura aos jovens. }\end{array}$ \\
\hline $\begin{array}{l}\text { "No campo de futebol nem todos podem jogar, } \\
\text { temos que esperar ficar mais velhos prá jogar, na } \\
\text { quadra nova, é tanta gente que ninguém joga mais } \\
\text { que } 5 \text { minutos. O jeito é inventar na rua mesmo." }\end{array}$ & $\begin{array}{l}\text { - Uso hierárquico e superlotação dos poucos } \\
\text { aparelhos urbanos para esporte. } \\
\text { - Exclusão do público mais jovem. } \\
\text { - Rua como alternativa. }\end{array}$ \\
\hline $\begin{array}{l}\text { "Este lugar aqui sempre foi assim. Começam a } \\
\text { construir as quadras, mas as empresas não pagam } \\
\text { os funcionários aí a obra para. Alguém está } \\
\text { pegando esse dinheiro e nós ficamos sem lugar } \\
\text { pra jogar". }\end{array}$ & $\begin{array}{l}\text { - Fatalismo naturalizando a corrupção. } \\
\text { - Descrença no poder público. }\end{array}$ \\
\hline $\begin{array}{l}\text { "Aqui se você não gosta de futebol não tem o } \\
\text { que fazer não. Bicicleta nem todos têm. O jeito é } \\
\text { arrumar um celular." }\end{array}$ & $\begin{array}{l}\text { - Hegemonia cultural do futebol sufocando } \\
\text { outras expressões de lazer e esporte. } \\
\text { - Celular como alternativa à ausência de } \\
\text { equipamentos de cultura e esporte. }\end{array}$ \\
\hline
\end{tabular}

Fonte: Elaborado pelos autores.

Em síntese, essas falas expressam dimensões fatalistas que corroboram o tema gerador anteriormente identificado. Ou seja, o tema dobradiça permite a compreensão de contradições que são compartilhadas por outros temas. É neste sentido que, tema gerador e dobradiça, refletem a perda da capacidade de ser sujeito na realidade, a impossibilidade de transformação do real e resultam na naturalização de contradições socioculturais. As representações também deixam a impressão acerca da descrença com 
o trato da coisa pública e falam dos poucos aparelhos urbanos de esporte e lazer e da dificuldade de encontrar espaço para todos.

As falas significativas levadas ao contexto de sala de aula na disciplina de Biologia foram apresentadas aos educandos na perspectiva de possibilitar uma reflexão crítica sobre a situação. Por isso, problematizações sobre os núcleos contraditórios presentes nas falas foram realizadas inicialmente em grupos pequenos e posteriormente lançadas ao debate do coletivo, sempre buscando envolver dimensões locais, micro e macrossociais. Os registros da discussão serviram para subsidiar os passos seguintes. Assim, os conhecimentos científicos selecionados no processo de redução temática, foram abordados na perspectiva de promover uma nova compreensão totalizadora da realidade local em estudo. Concomitantemente aos debates, buscou-se sempre organizar sínteses analíticas que considerassem a concretude da realidade sociocultural, sua historicidade e por isso sua inconclusão, apontando caminhos ético-críticos para a superação das "situações-limites" expressas pelas falas significativas. Essa organização foi recorrente em todas as aulas desenvolvidas sobre esse tema gerador identificado, tendo como subsídio metodológico os momentos pedagógicos supracitados como as contribuições de Delizoicov et al. (2011), Demartini, (2017), Silva (2004; 2007), Lamback (2013) e Gomes (2014).

Ao problematizar essas falas significativas com os educandos, num movimento fundamentado na (Figura 2), proposições começaram a surgir. À medida que tomam consciência da situação, os educandos entendem que a transformação da condição existente exige ação das pessoas da comunidade. Neste sentido, cobrando também a participação do docente e da gestão escolar, questionaram sobre a possibilidade de utilizar o espaço da escola no período da tarde, quando está fechada, e aos finais de semana para realizar atividades de lazer, cultura e esporte. Neste diálogo com a gestão escolar, a possibilidade de utilizar um pequeno espaço entre os prédios permitiu a construção de uma quadra de vôlei dentro da escola. Vôlei porque é um esporte marginalizado na cidade, porque é coletivo e permite a vivência de uma prática nova no universo esportivo local, dominado majoritariamente pelo futebol. A bola, a rede e as fitas de demarcação foram doadas por vereadores e pessoas da comunidade, as madeiras para montar o suporte da rede foram cortadas pelos educandos na mata próxima à escola.

Os educandos vivenciaram a dimensão epistemológica crítica, isto é, a compreensão de que a tomada de consciência tem que se alongar em ações concretas para atingirmos a conscientização (consciência em ação) - expressão da práxis autêntica de Freire (1987). O resgate da potencialidade transformadora do real restaura as dimensões ontológicas antes negadas.

Por isso, a experiência foi interessante e muitos alunos que frequentaram a escola se sentiram assistidos acerca do direito a uma área para esporte e lazer. Mas a gestão escolar resolveu encerrar a atividade devido à falta de estrutura física, aos estragos causados ao prédio com os jogos, a entrada de não educandos no prédio e a falta de profissionais para acompanhar os jovens. 
Uma vez tendo vivenciado o poder que a organização coletiva pode apresentar, percebendo como podem restaurar a capacidade de mudar as condições concretas existentes, os estudantes não se conformaram e envolveram o docente em uma nova iniciativa. Um projeto foi elaborado e encaminhado à Prefeitura acompanhado de aproximadamente 200 assinaturas de membros da comunidade escolar. Neste havia a descrição de todo um processo de mobilização dos educandos para ocupar e construir uma quadra de vôlei num terreno em frente à escola, bem como orçamento de materiais que foram solicitados à Prefeitura. A intenção era de que os educandos construíssem com seu trabalho, valorizando o esforço coletivo e estimulando o sentimento de pertencimento àquela obra.

O local escolhido pelos educandos foi simbólico. Um terreno público localizado na esquina da instituição escolar apresentando os primórdios da fundação de uma quadra esportiva que teve sua construção iniciada e nunca terminada. Os relatos da comunidade, expressando profunda descrença com a política, explicam o fato como resultado da corrupção e do descaso de gestões anteriores no Município e no Estado.

Foram várias semanas carpindo o terreno em mutirões aos finais de semana. Quando o terreno estava limpo, a Prefeitura percebeu a seriedade da mobilização e aceitou participar do projeto fornecendo cinco caminhões de areia que foi distribuída pelos educandos no terreno, dando forma à quadra de vôlei. As hastes de madeira para fixar a rede foram novamente cortadas em uma área de mata próxima à escola. Ao término os educandos e a comunidade conquistaram um espaço potencialmente capaz de atacar as contradições sociais presentes nas falas significativas que denunciavam a falta de aparelhos urbanos para esporte e lazer. Campeonatos, treinos e jogos passaram a ser realizados, e não tardou a instalação de traves de madeira para o uso do espaço também para o futebol (Figura 6).

Figura 6. Processo de construção da quadra de vôlei de areia

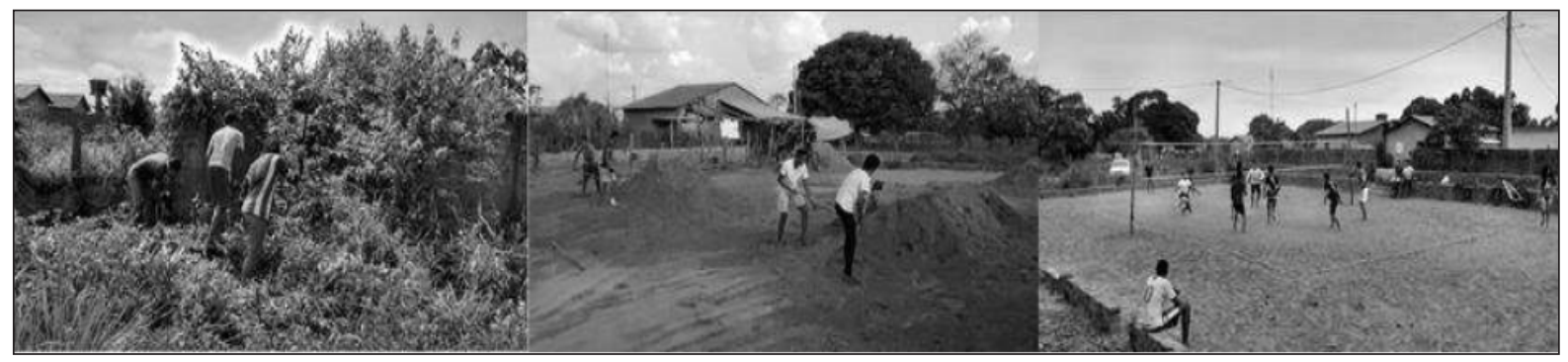

Fonte: Acervo dos autores.

Toda esta mobilização, muito sinteticamente apresentada, é evidência concreta da busca dos educandos que tomam consciência das contradições vivenciadas e procuram resgatar a sua posição, como sujeito na definição dos rumos da realidade local. A comunicação com o poder público mostrou aos educandos que, mesmo com muita dificuldade, alguma possibilidade existe e que a coletividade é o caminho para conquistar voz e representação. 
Em síntese, a análise crítica da realidade possibilitou ao coletivo dos educandos o resgate de sua ontologia histórica por meio da práxis autêntica (Freire, 1987). A vivência deste processo humanizador motiva a continuar o enfrentamento e desvelamento das contradições socioculturais. Neste sentido, para Freire (1987), "Quanto mais as massas populares desvelam a realidade objetiva e desafiadora sobre a qual elas devem incidir sua ação transformadora, tanto mais se "inserem" nela criticamente" (p. 22).

Concluímos este breve relato ressaltando que a pedagogia libertadora expressou através da dialogicidade problematizadora, a materialidade negativa da educação ao resgatar as "situações-limites" e a forma como estas eram percebidas, como obstáculos a serem superados (Silva, 2004). Portanto, o alicerce da prática curricular ético-crítica, desenvolvida no ensino de ciências e biologia a partir da perspectiva da abordagem temática freireana, esteve ancorado na realidade concreta, transformada pela ação praxiológica autêntica.

\section{Conclusões e Implicações}

Oinconformismo diante das desumanizadoras práticas curriculares convencionais levou à busca por uma pedagogia que colocasse a humanização como objetivo central. Neste sentido, o presente trabalho se orientou a partir do seguinte problema de pesquisa: em que medida a educação libertadora pode fundamentar práticas curriculares transformadoras da realidade sociocultural injusta no contexto de uma escola estadual de ensino médio de São Francisco do Brejão (MA)? O objetivo foi compreender a realidade escolar em seus múltiplos condicionantes e propor práticas curriculares éticocríticas que buscassem a consolidação de uma educação humanizadora. Para tanto foi elaborado um currículo local por meio do processo de "investigação temática" com a obtenção de um "tema gerador" que possibilitasse a organização da programação curricular a partir das contradições socioculturais. Um tema dobradiça também foi inserido e desenvolvido, resultando numa mobilização social para a construção de uma quadra de vôlei. Portanto, tratou-se de uma pesquisa de natureza qualitativa com abordagem do tipo pesquisa-ação que ultrapassou os limites da instituição escolar e ganhou concretude na estrutura social local.

O processo de construção curricular via abordagem temática freireana envolveu a caracterização do contexto local com a exposição de propriedades que possibilitaram uma compreensão ampla e relacional. O tema gerador foi obtido por meio das falas significativas, a saber: "Sou uma pessoa humilde, por isso não gosto de muita mudança". O contratema formulado foi expresso como: "Resgatando a dimensão transformadora da existência humana: sujeitos na produção da existência coletiva". Estes, articulados pelas dimensões da realidade local e pelas falas significativas, permitiram a construção de uma rede temática que auxiliou na formulação da programação curricular para o ensino de Ciências e Biologia. Por fim, como derivação do tratamento de um tema dobradiça: "a ausência dos aparelhos urbanos de lazer e esporte e a passividade da comunidade diante deste fato", uma mobilização social encabeçada pelos educandos gerou a construção de 
uma quadra de vôlei de areia como forma de assegurar algum espaço para esporte e lazer aos jovens do Município.

Buscando o esclarecimento acerca da dinâmica da investigação temática (Freire, 1987), a presente pesquisa vai ao encontro de outros trabalhos da área que buscam elucidar os processos de representação e análise envolvidos na redução temática.

Um ponto central a ser destacado é a articulação intrínseca entre tema gerador, contratema e temas dobradiças. Se os temas geradores constituem os elementos curriculares que apresentam as contradições socioculturais expressas nas visões de mundo dos educandos e comunidade - por meio das "situações-limites" (Freire, 1987)/“falas significativas" (Silva, 2004) - o confronto a estas compreensões é estabelecido dialogicamente por processos de problematização. Este movimento apresenta no horizonte a visão docente sistematizada, ou seja, o contratema como horizonte político e ético-crítico (Silva, 2004). Mas no esforço de compreensão das relações estabelecidas pelas contradições socioculturais, em diversos níveis de amplitude, as inserções de alguns temas auxiliam na compreensão da realidade concreta. Estes são chamados de temas dobradiças (Freire, 1987).

Por isso, apontamos que os temas dobradiças (Freire, 1987) não devem ser compreendidos como apartados do processo de investigação temática, mas como complemento analítico da redução temática. Assim, não sendo elemento externo, estão, pelo contrário, vinculados às contradições socioculturais não explicitadas no contexto local e encontram-se delimitado pelo próprio tema gerador. Não é possível a existência de um tema dobradiça desvinculado de um tema gerador - por isso não deve ser utilizado como mecanismo adaptativo para se ensinar conhecimentos previamente estabelecidos e desconectados da realidade sociocultural local. Compreender o tema dobradiça como elemento orgânico ao processo de investigação temática perpassa o reconhecimento do seu papel na busca pela totalização na compreensão da realidade concreta.

Outra questão importante e recorrente nos processos de investigação temática é a organização da prática pedagógica e curricular com base na visão docente (contratema) e não a partir da compreensão de mundo expressa pelos educandos e comunidade. Neste sentido, as falas significativas (Silva, 2004) buscam garantir a concretude das contradições socioculturais como ponto de partida para o processo de investigação temática.

O conhecimento sistematizado selecionado também tem uma relação de engajamento na superação das contradições que as falas significativas trazem, portanto, não pecam por uma generalização imprópria em relação à problemática abordada.

Assim, perspectiva de trabalhar com falas significativas (Silva, 2004), pode contribuir para alguns aspectos:

- Apresentar parâmetro para a seleção dos conhecimentos sistematizados que efetivamente propiciem um desvelamento da realidade.

- Evitar que a visão de mundo dos educadores seja tomada como ponto de partida para a organização programática, garantindo a concretude da visão de mundo dos educandos como primeira referência. 
Em síntese, o trabalho buscou assegurar a dialogicidade fundante da perspectiva libertadora - para isso orientou-se pelas contradições socioculturais, pelo seu tratamento em dinâmicas de problematização e pelas proposições transformadoras. Ou seja, a pedagogia libertadora, por meio do diálogo e da práxis autêntica, possibilitou a afirmação da exterioridade negada, na construção de uma racionalidade ético-crítica (Dussel, 2000).

A reflexão sobre a práxis autêntica a partir de Freire apresentou-se como possibilidade de estruturação do processo educativo humanizador e crítico. Isso ficou evidente na expressão de resistência às práticas curriculares convencionais e na possibilidade de resgate da autonomia docente e dos educandos.

Devido à dimensão exigida, o presente texto limitou-se à dimensão programática do diálogo, ou seja, não foi exposta a etapa realizada em sala de aula a partir dos Momentos Pedagógicos (Delizoicov et al., 2011). É importante ressaltar que, por ter se restringido à disciplina de Biologia, esse trabalho não conseguiu garantir a interdisciplinaridade - necessária para uma compreensão ampla e rigorosa das contradições socioculturais. Também devido a diferentes posições político-pedagógicas, não houve possibilidade de problematização junto ao corpo docente escolar.

Apontamos para a necessidade de se pensar a construção curricular a partir das demandas concretas das realidades vivenciadas pelos educandos. O currículo local não implica em uma restrição ao local, mas significa partir da concretude de suas negatividades para vislumbrar a ampliação dos horizontes rumo a uma compreensão em totalidade. Além disso, o processo de investigação temática possibilita a educadores e educandos resgatarem seus papeis de protagonistas no processo educativo, superando os tradicionais "pacotes curriculares" que impostos, tratam a realidade concreta de forma marginal.

Dessa forma, a construção curricular via abordagem temática no ensino de Ciências e Biologia, possibilita mediante a práxis autêntica, que educadores e educandos atuem a partir da indissociabilidade entre a racionalidade ético-crítica no fazer educativo e o resgate como protagonistas na transformação social. Ao contemplar as diferentes visões de mundo e considerar todos os sujeitos históricos, busca a compreensão crítica da realidade concreta e da inconclusão humana, articulada com uma proposta educacional comprometida com o Ser Mais.

\section{Referências}

Alves, A. H. B., \& Silva, A. F. G. (2015). Manifestações de Obstáculos Gnosiológicos para a seleção de Conteúdos na Implementação de um Currículo Crítico em Ciências Naturais. Alexandria: Revista em Educação em Ciências e Tenologia, 8(1), 181-207. https://doi.org/10.5007/1982-5153.2015v8n1p181

Apple, M. W. (2006). Ideologia e currículo. Artmed.

Barbier, R. (1985). A pesquisa-ação na instituição educativa. Zahar. 
Bernardi, L. S., Stuani, G. M., Delizoicov, N. C. (2015). Um projeto Interdisciplinar: abordagem temática freireana no estágio de docência do curso de licenciatura intercultural indígena. Revista Pedagógica, 17(34), 192-207. https://doi.org/10.22196/ rp.v17i34.2925

Coelho, J. C. (2010). Processos formativos na direção da educação transformadora: temas-dobradiça como contribuição para a abordagem temática (Tese de Doutorado, Universidade Federal de Santa Catarina, Florianópolis, Santa Catarina). Repositório Institucional da UFSC. http://repositorio.ufsc.br/handle/123456789/103333

Delizoicov, D. (2008). La educación em ciencias y la perspectiva de Paulo Freire. Alexandria: Revista em Educação em Ciências e Tenologia, 1(2), 37-62. https://periodicos. ufsc.br/index.php/alexandria/article/view/37486/28782

Delizoicov, D., Angotti, J. A., \& Pernambuco, M. M.(2011). Ensino de ciências: fundamentos e métodos. Cortez.

Demartini, G. R. (2015). Articulação entre Paulo Freire e Herbert Marcuse para uma educação sexual humanizadora (Dissertação de Mestrado, Universidade Federal de São Carlos, Sorocaba, São Paulo). Repositório Institucional da UFSCar. https://repositorio. ufscar.br/handle/ufscar/2807

Demartini, G. R. (03-06 de julho, 2017). Abordagem temática freireana em uma escola estadual no Maranhão. Anais do XI Encontro Nacional de Pesquisa em Educação em Ciências (ENPEC). http://www.abrapecnet.org.br/enpec/xi-enpec/anais/resumos/ R1415-1.pdf

Demartini, G. R., \& Silva, A. F. G. (2016). Articulação entre Paulo Freire e Herbert Marcuse: educação sexual emancipatória em uma escola estadual do município de Sorocaba-SP. Revista E-Curriculum 14(1), 56-81. http://revistas.pucsp.br/curriculum/ article/view/26333

Dussel, E. (2000). Ética da libertação: na idade da globalização e da exclusão. Vozes.

Fairclough, N. (2001). Discurso e mudança social. Editora UnB.

Franco, M. A. S. (2005). Pedagogia da pesquisa-ação. Educação e Pesquisa, 31(3), 483502.

Freire, P. (2011). Pedagogia da autonomia. Paz e Terra.

Freire, P. (1983). Extensão ou comunicação. Paz e Terra.

Freire, P. (1987). Pedagogia do oprimido. Paz e Terra.

Furlan, A. B. S. (2015). Concepção de um currículo crítico: a ética como referência praxiológica (Dissertação de Mestrado, Universidade Federal de São Carlos, Sorocaba, São Paulo). Repositório Institucional da UFSCar. https://repositorio.ufscar.br/handle/ ufscar/6939 
Furlan, A. B. S., Ricci, E. C. Gomes, C. G. S., \& Silva, A. F. G. (05-09 de dezembro, 2011). Abordagem temática no currículo de ciências: a perspectiva ético-critica na concepção de lixo como condição humana. Anais do VIII Encontro Nacional de Pesquisa em Educação em Ciências (ENPEC). http://abrapecnet.org.br/atas_enpec/viiienpec/resumos/R04121.pdf

Gomes, C.G.S. (2014).Da experiência não autêntica à busca porvivências humanizadoras: prática curricular freireana em ciências (Dissertação de Mestrado, Universidade Federal de São Carlos, Sorocaba, São Paulo). Repositório Institucional da UFSCar. https:// repositorio.ufscar.br/handle/ufscar/8385

Halmenschlager, K. R., Monano, G. D., \& Stragliotto, M. (08 de setembro, 2017). Abordagem Temática na Educação do Campo: Desafios no âmbito do Estágio Docência. X Congreso Internacional sobre Investigación en la Didáctica de las Ciencias.

Instituto Brasileiro de Geografia e Estatística - IBGE. (2019). Indicadores sociais municipais.

Lambach, M. (2013). Formação permanente de professores de química da EJA na perspectiva dialógico problematizadora freireana (Tese de Doutorado, Universidade Federal de Santa Catarina, Florianópolis, Santa Catarina). Repositório Institucional da UFSC. https://repositorio.ufsc.br/xmlui/handle/123456789/122825

Novais, E. S. P., Fonseca, K. N., Solino, A. P., Sousa, P. S. S., Silva, R. M., \& Gehlen, S. T. (2017). O processo de Redução Temática na Formação de Professores em Iguaí-BA. Alexandria: Revista de Educação em Ciências e Tecnologia, 10(1), 77-103. https://doi. org/10.5007/1982-5153.2017v10n2p77

Oliveira, D. S. (2016). Apropriações do Tema Gerador no Ensino de Ciências (Dissertação de Mestrado, Universidade Federal da Bahia, Salvador, Bahia). Repositório Institucional da UFBA. https://ppgefhc.ufba.br/pt-br/apropriacoes-do-tema-gerador-no-ensino-deciencias

Silva, A. F. G. (2004). A construção do currículo na perspectiva popular crítica: das falas significativas às práticas contextualizadas (Tese de Doutorado, Pontifícia Universidade Católica de São Paulo, São Paulo, São Paulo). Biblioteca Digital: Teses e Dissertações PUC. https://tede2.pucsp.br/handle/handle/22098

Silva, A. F. G. (Org.). (2007). A busca do tema gerador na práxis da educação popular. Gráfica Popular.

Silva, R. M., Solino, A. P., Sousa, P. S. S., Fonseca, K. N., Novais, E. S. P. \& Gehlen, S. T. (2016). Situações-Limite na formação de professores de ciências na perspectiva freireana: da percepção da realidade à dimensão pedagógica. Investigações em Ensino de Ciências (IENCI), 21(3), 127-151. https://www.if.ufrgs.br/cref/ojs/index.php/ienci/ article/view/671/447 
Silva, R. M., \& Gehlen, S. T. (2016). Investigação Temática na Formação de Professores de Ciências em Pau Brasil-BA: Compreensões acerca de um tema gerador. Revista Ensaio, 18(2),147-169. https://doi.org/10.1590/1983-21172016180207

Santos, J. S. (2020). A dimensão axiológica no desenvolvimento e implementação de atividades didático-pedagógicas via tema gerador (Dissertação de Mestrado, Universidade Estadual de Santa Cruz, Ilhéus, Bahia). Biblioteca Digital de Teses e Dissertações UESC. http://www.biblioteca.uesc.br/biblioteca/bdtd/201810933D.pdf

Saul, A. P. (2015). Para mudar a prática da formação continuada de educadores: uma pesquisa inspirada no referencial teórico-metodológico de Paulo Freire (Tese de Doutorado, Pontifícia Universidade Católica de São Paulo, São Paulo, São Paulo). Biblioteca Digital: Teses e Dissertações PUC. https://tede2.pucsp.br/handle/handle/9519

Saul, A., \& Saul, A. M. (2017). A metodologia da investigação temática: elementos político-epistemológicos de uma práxis de pesquisa crítico-emancipatória. Revista e-Curriculum, 15(2), 429-454. https://doi.org/10.23925/1809-3876.2017v15i2p429-454

Sousa, P. S., Solino, A. P., Figueiredo, P. S., \& Gehlen, S. T. (2014). Investigação temática no contexto do ensino de ciências: relações entre a abordagem temática freireana e a práxis curricular via tema gerador. Alexandria: Revista de Educação em Ciência e Tecnologia, 7(2), 155-177. https://periodicos.ufsc.br/index.php/alexandria/article/ view/38222

Thiollent, M. (1986). Metodologia da Pesquisa-Ação. Cortez/Autores Associados.

Triviños, A. N. (1987). Introdução à pesquisa em ciências sociais: a pesquisa qualitativa em educação. Atlas S.A.

Vale, F. (2012). Lá entre os brejos. Ética. 


\section{Gabriel Ribeiro Demartini \\ Universidade Federal de São Carlos (UFSCar-So) Sorocaba, São Paulo, Brasil grdemartini@yahoo.com.br

\author{
Antonio Fernando Gouvêa da Silva \\ Universidade Federal de São Carlos (UFSCar-So) \\ Sorocaba, São Paulo, Brasil \\ gova@uol.com.br
}

Editora Responsável

Stefannie Ibraim

Manifestação de Atenção às Boas Práticas Científicas e de Isenção de Interesse

Os autores declaram ter cuidado de aspectos éticos ao longo do desenvolvimento da pesquisa e não ter qualquer interesse concorrente ou relações pessoais que possam ter influenciado o trabalho relatado no texto. 